\title{
Summary of Trends in Photovoltaic Patent Activity
}

L. O. Levine

June 1984

Prepared for the U.S. Department of Energy under Contract DE-ACO6-76RLO 1830

Pacific Northwest Laboratory Operated for the U.S. Department of Energy by Battelle Memorial Institute 


\title{
DISCLAIMER
}

This report was prepared as an account of work sponsored by an agency of the United States Government. Neither the United States Government nor any agency thereof, nor any of their employees, makes any warranty, express or implied, or assumes any legal liability or responsibility for the accuracy, completeness, or usefulness of any information, apparatus, product, or process disclosed, or represents that its use would not infringe privately owned rights. Reference herein to any specific commercial product, process, or service by trade name, trademark, manufacturer, or otherwise, does not necessarily constitute or imply its endorsement, recommendation, or favoring by the United States Government or any agency thereof. The views and opinions of authors expressed herein do not necessarily state or reflect those of the United States Government or any agency thereof.

\author{
PACIFIC NORTHWEST LABORATORY \\ operated by \\ BATTELLE \\ for the \\ UNITED STATES DEPARTMENT OF ENERGY \\ under Contract DE-AC06-76RLO 1830
}

\begin{tabular}{|c|c|}
\hline \multicolumn{2}{|c|}{ Printed in the United States of America } \\
\hline \multicolumn{2}{|c|}{$\begin{array}{l}\text { Available from } \\
\text { A }\end{array}$} \\
\hline \multirow{2}{*}{\multicolumn{2}{|c|}{$\begin{array}{l}\text { National Technical Information Service } \\
\text { United States Department of Commerce }\end{array}$}} \\
\hline & \\
\hline \multicolumn{2}{|c|}{5285 Port Royal Road } \\
\hline \multicolumn{2}{|c|}{ Springfield, Virginia 22161} \\
\hline \multirow{2}{*}{\multicolumn{2}{|c|}{$\begin{array}{l}\text { NTIS Price Codes } \\
\text { Microfiche A01 }\end{array}$}} \\
\hline & \\
\hline \multicolumn{2}{|c|}{ Printed Copy } \\
\hline & \\
\hline Pages & Codes \\
\hline 001-025 & $\mathrm{A} 02$ \\
\hline $026-050$ & A03 \\
\hline $051-075$ & $\mathrm{~A} 04$ \\
\hline $076-100$ & A05 \\
\hline $101-125$ & A06 \\
\hline $126-150$ & A07 \\
\hline $151-175$ & $\mathrm{~A} 08$ \\
\hline $176-200$ & $A 09$ \\
\hline $201-225$ & A010 \\
\hline $226-250$ & A011 \\
\hline $251-275$ & А 012 \\
\hline $276-300$ & A013 \\
\hline
\end{tabular}


PNL -5150

UC -63

SUMMARY OF TRENDS IN

PHOTOVOLTAIC PATENT ACTIVITY

L. 0 . Levine

June 1984

Prepared for the Photovoltaics Division of the U.S. Department of Energy under Contract 0E-AC06-76RL0 1830

Pacific Northwest Laboratory Richland, Washington 99352 
. 
SUMMARY

This report presents information on patent activity for inventions concerning photovoltaic cell technology. Such information can aid in the assessment of the status and direction of technological development.

A total of 729 U.S. patents that issued between mid-1962 and the end of 1982, were individually exalnined and classified into several technical categories for this study. Computerized analysis of trends in patent activity among major technical categories revealed the following major findings:

- The level of inventive activity increased dramatically in the mid1970's. It appears to have peaked $i n 1978$ and remained steady through 1980.

o The data indicates that, beginning in 1978, an increasing proportion of inventions were among approaches other than the conventional $\mathrm{Cz}$ type cells, specifically thin film and concentrator cells.

o Thin $\mathrm{f} i 1 \mathrm{~m}$ and $\mathrm{Cz}$ type photovoltaic cells represent two-thirds of the patents analyzed.

- Among thin film patents, silicon and cadmium containing cells represent about two-thirds of the patents analyzed.

Further insight into recent trends could be obtained by adding more recently issued patents to the database. 

. 


\section{ACKNOWLEDGEMENTS}

The author of this document would like to acknowledge the contributions of several members of the Pacific Northwest Laboratory research staff. Raymond L. Watts provided technical consultation for the photovoltaic technology classification and the interpretation of the results. Antoinette L. Slavich and Kenneth $W$. Burk provided assistance with the computer analysis.

This work would not have been possible without the previous patent analysis in photovoltaic technology undertaken by Richard S. Campbell.

This research was performed as part of the Photovoltaic Technology Assessment project for the Department of Energy under the direction of Andrew Krantz. 


.




\section{CONTENTS}

SUMMARY

ACKNOWLEOGMENTS

1.0 INTRODUCTION BACKGROUND .

OBJECTIVES

2.0 PHOTOVOLTAIC PROBLEM DOMAIN

INTRODUCT ION

PHOTOVOLTAIC CELLS

TECHNOLOGY CATEGORIZATION .

3.0 METHODOLOGY

PATENT SEARCH

PATENT ACTIVITY •

4.0 RESULTS

AGGREGATE ACTIVITY •

CELL TYPES •

THIN FILM PATENTS 


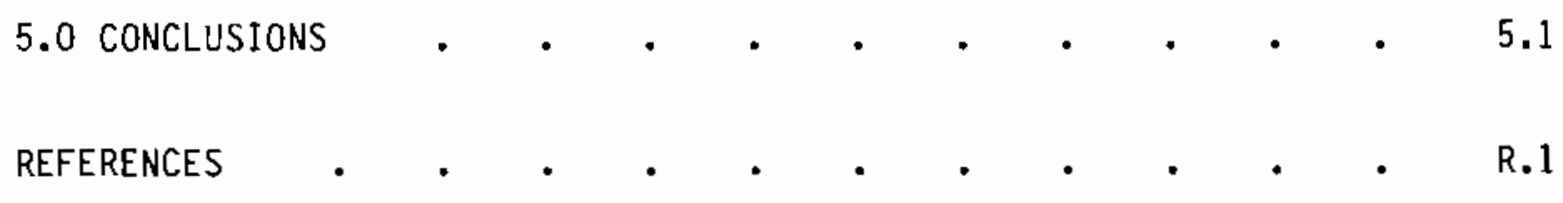




\section{FIGURES}

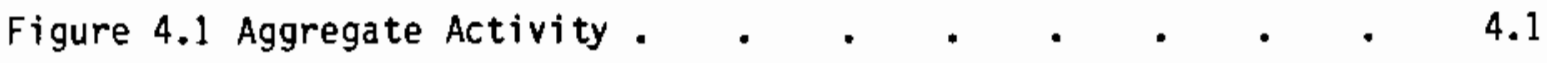

Figure 4.2 Photovoltaic Patents - Percentage by Cell Type . $\quad 4.2$

Figure 4.3 Patent Activity by Cell Type -- Cz, Polycrystaline, Concentrator, Thin Film 4.3

Figure 4.4 Patent Activity by Cell Type -- Ribbon, Generic/Several, other $\quad$. . . 4.4

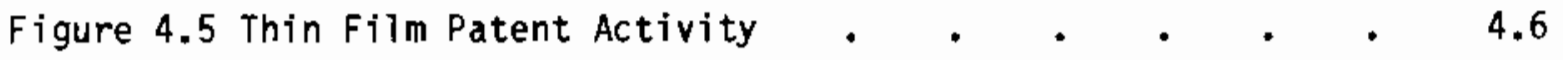

Figure 4.6 Thin Film Patent Activity -- Silicon/Cadmium Comparison $\quad$ • 4.7

\section{TABLES}

2.1 Patent Categorization Coding . . . . . . . . 2.3

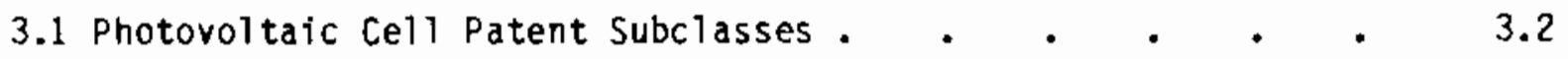

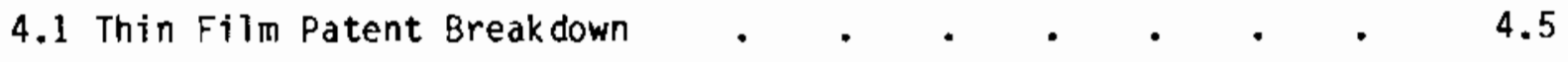





\subsection{INTRODUCTION}

BACKGROUND

Pacific Northwest Laboratory (PNL) has developed analytical procedures useful for tracking technological trends. Several of these procedures involve the use of patents (Campbell and Nieves 1979, Garrett-Price et al. 1984, Levine, Ashton, and Campbell 1984, Campbell and Levine 1984). Because of the legal requirements of the patent system, changes in patents frequently procede changes in market developments. In addition, technology indicators derived from patent data can also precede changes in indicators derived from technical literature on the same topic (Campbell 1983a).

Some of the issues addressed in the patent analysis include the following:

- Is the relative emphasis among different technical approaches changing?

- Are the developments temporally well distributed or are there strong temporal trends or peaks?

0 If there are peaks or strong trends, can they be correlated with economic or societal driving forces?

\section{OBJECTIVES}

The purpose of this report is to supplement PNL's ongoing photovoltaic technology assessment -- tracking R\&0 progress and company PV production -which is intended to assist the Photovoltaic Division of the Department of Energy in its program planning efforts. The report builds on patent-based studies of photovoltaic cells in research work completed for the National Science Foundation (Campbell and Levine 1994). That research, designed to develop and test technology indicators based on patent data, identified and acquired the photovoltaic patents which are analyzed in greater technical detail here. While PNL has developed a family of indicators to measure technological change, this report is 1 imited to quantifying the level of inventive activity in photovolotaic technology. 


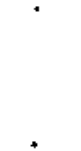




\subsection{PHOTOVOLTAIC PROBLEM DOMAIN}

INTRODUCTION

In this study, we maintain a focus on technological problem domains. These are analogous to the "problem domain" concept as applied to scientific disciplines by Chubin and Studer (1979) -- an area which possesses a central set of explanatory problems or questions. The technological problem domain, then, defines inventive activity that derives its motivation from common technological and market opportunities.

This notion of problem domain, however, does not preclude there being fundamentally different approaches for solving the key problems within a problem domain. In fact, an important attribute of problem domains is the number of distinct technical approaches that coexist. While the marketplace ultimately determines which approach, or approaches, will survive, many approaches can exist at any point in time. Patent data, through the indicators described below, provide a unique view of the interplay of these competing technical approaches.

\section{PHOTOVOLTAIC CELLS}

The problem domain for this study was defined by the belief that the most crucial developmental concerns focused on cell technology, which includes materials, doping, contacts, interconnections, and module construction. Patents related to mechanical solar tracking, satellite panel deployment mechanisms, batteries, inverters, etc. were excluded from analysis. This doesn't mean that these related technologies are unimportant, but rather that the major thrust of R\&D efforts has been directed toward photovoltaic cells and that improvements in cell performance and manufacturing economics are the key issues in photovoltaics development.

The overriding issue for photovoltaic technology is to improve performance and decrease cost to make the technology economically competitive with other forms of electric power generation (whose cost is assumed to increase over time). In photovoltaics, the general problems are as follows: 
1) producing inexpensive substrate materials

2) producing inexpensive substrates themselves

3) producing active layers in the substrates

4) reducing recombination losses for improved efficiency

5) reducing transmission and reflective losses in the cells' protective covers

6) reducing ohmic losses in conductors and connectors

7) maintaining high yield

8) matching cell response spectra to available light

These goals can be approached in various ways. For example, the goal of reducing the amount of expensive active layer materials used to produce a cell has led to several ways of growing thin single crystal webs, sheets and strips, as well as several ways of depositing or growing amorphous or polycrystalline thin film cells. Another approach increases cell output by concentrating incoming light with inexpensive lenses or reflectors. In addition, fluorescent covers can increase cell output by shifting the spectrum of incoming light to match the response curves of the cells.

IECHNOLOGY CATEGORIZATION

Prior studies (Wiseman 1983, Levine, Ashton, and Campbell 1984) have found that greater insight into the dynamics of technological development can be obtained from patent data when the patents are grouped into specific technical categories. After patents in an area of interest have been appropriately grouped, activity plots can be used to show changes in emphasis over time. One area of the technology may receive most of the attention for a period until a breakthrough or other conditions motivate a shift in focus.

After indepth review, the patents were categorized based on cell type and process step. In addition, patents related to thin film techniques were further categorized by type of material. A listing of the numerical coding scheme is provided in Table 2.1 . 
TABLE 2.1. Technology Categorization Coding Scheme

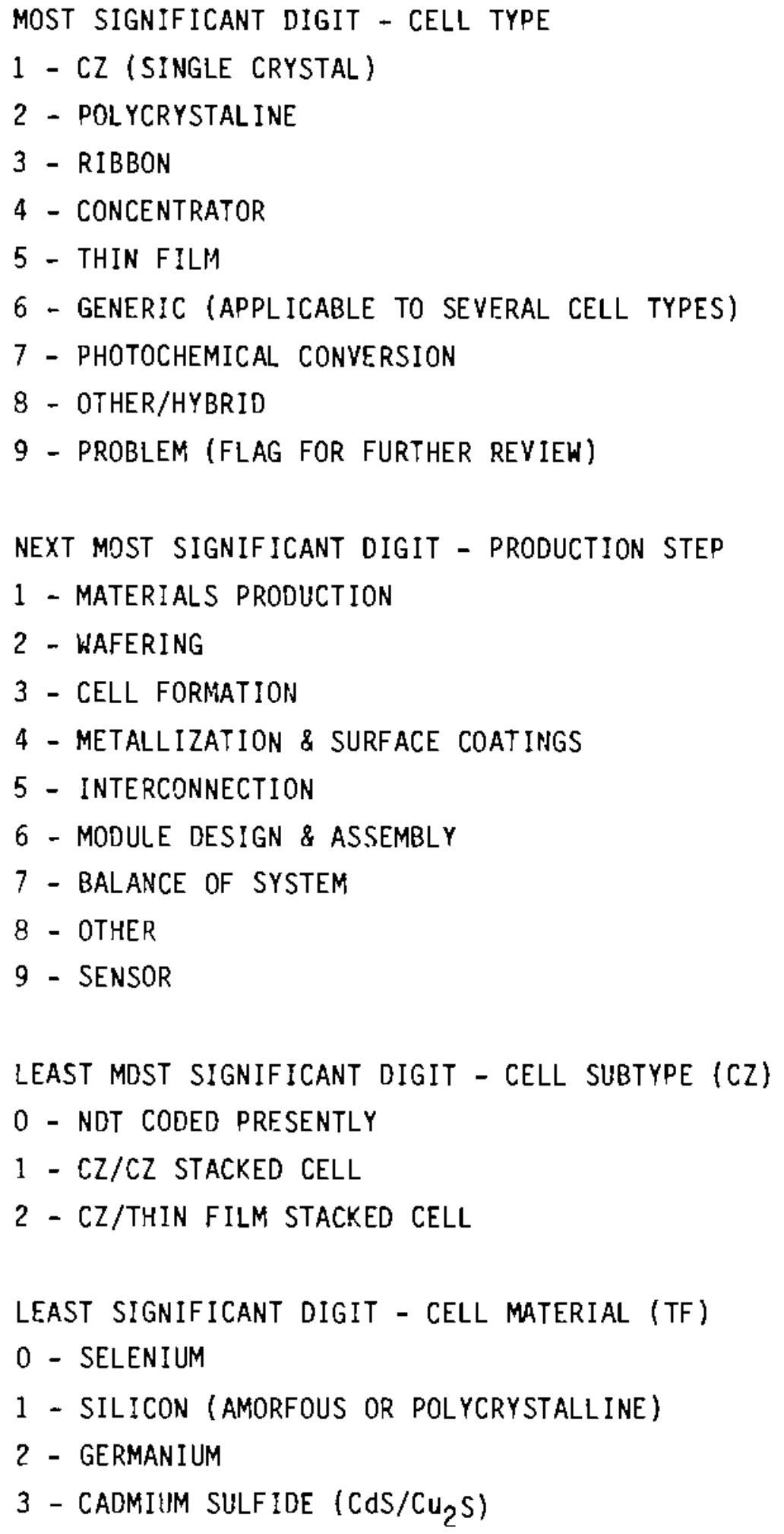


TABLE 2.1 continued-

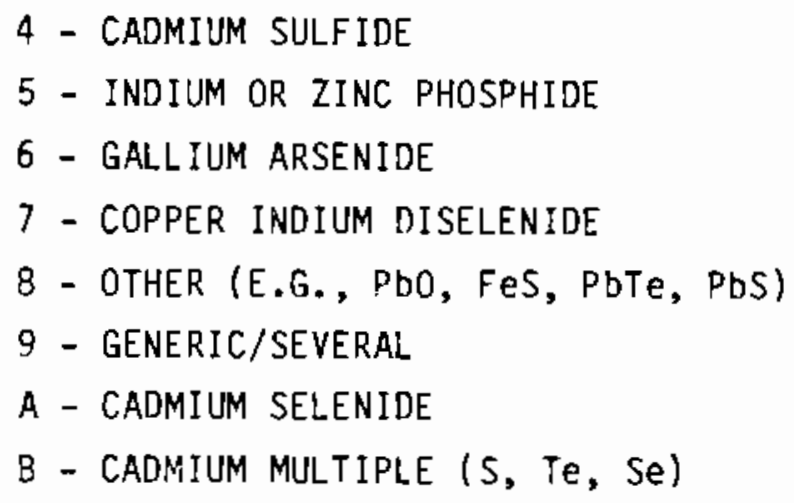




\subsection{METHODOLOGY}

This section outlines the methodology utilized in this report. The patent indicator activity, i.e., the number of patents filed per year, is discussed. In addition, the patent search strategy used to identify the patents is described.

\section{PATENT SEARCH}

Meaningful interpretation of patent indicators is contingent upon the identification of the set of relevant patents. The greater the precision with which the set is defined, the greater will be the clarity of the indicators and the confidence with which they can be used. Two conditions for defining the patent set must be met. First, one should have a clear understanding of which patents are relevant, and which are not. Second, the search for relevant patents must be reasonably complete and accurate. patents.

Utilizing commercially available patent data bases, patents issued from 1947-1982 were identified based on original or cross-classification into one or more of the patent subclasses within Class 136 which are listed in Table 3.1. Patents which issued in 1983 or the beginning of 1984 are not included. These subclasses yielded a total of 912 patents.

These patents were individually examined for their relevance to photovoltaic development. The subclasses include patents for inventions related to the application of photovoltaic cells to sensors rather than power generation. While some patents in this category were judged to have generic relevance to power generation and were included for analysis, other patents were found irrelevant and discarded. The reduced set included 851 patents.

of these 851 patents, only those that issued before mid-1962. were examined and categorized into several detailed technical categories. However, the 729 patents categorized represent approximately $85 \%$ of the total number of patents, and thus provide a good approximation of the total distribution among the technical categories. 
TABLE 3.1. Photovoltaic cell patent subclasses (U.S. Patent office 1979)

CLASS 136 BATTERIES, THERMOELECTRIC AND PHOTOELECTRIC

PHOTOELECTRIC

Subclass

249

..Monolithic semiconductor

250

..Particulate or spherical semiconductor

251

..Encapsulated or with housing

252

. Cells

255

...Shottky, graded doping, plural junction or special geometry

256 ..Contact, coating, or surface geometry

257 ...Luminescent layer or optical filter

258 ..Polycrystalline or amorphous semiconductor

259 ..with concentrator, housing, cooling means, or encapsulated

260 ..Cadmium containing

261 ..Silicon or germanium containing

262 ..Gallium containing

263

..Organic active material containing

264 ...Selenium or tellurium containing

265 ..copper, lead, or zinc containing 


\section{PATENT ACTIVITY}

Patents are, in effect, deeds. It is possible to detect the emergence of a major real estate development by looking at the level of activity recorded at the registrar of deeds. Similarly, increasing numbers of individuals or firms staxing claims in a technological area provides strong evidence that someone has struck a potentialiy important technological vein. At a minimum, increasing patent activity shows that inventors believe that: 1) there is a potential economic payoff to solving a particuTar problem, and 2) the problem has one or more technical solutions.

Overall inventive activity can be measured in several ways from patents: 1) number of new patents, 2) number of new inventors in the field, 3) number of inventors previously patenting in the area, 4) number of new firms, 5) number of firms previously in the area. These all reflect different parts of the same movement toward or away from a technology depending on how it is doing on the "technological stock market".

In this study activity is measured by the number of patents filed per year. Since patent applications are not published in the U.S. patent system, activity is derived from the issued patents in a particular area at the time of analysis. The dates when applications for these patents were filed are then used to construct time series of the number of patents filed in a given year. Filing year is used because it eliminates variation in the period of processing patents (usualiy 1-1/2 - 2 years), thus increasing the confidence in the interpretation of the analysis results. This has the effect, however, of undercounting the patents filed in the last two years. For example, because this study includes patents issued through 1982, this indicator showes no patents filed in 1982 and only a few filed in 1981 . This does not mean that activity declined in those years, simply that patents filed in 1981 and 1982 do not appear until they issued in 1983 and 1984, or later. Thus, activity plots based upon filing year show a characteristic decline in the last two filing years covered. 


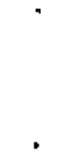




\subsection{RESULTS}

Because of the high degree of disaggregation for the technology categories, computer analysis of the constructed database revealed several subcategories with only a few patents. Thus interpretation of trends for these groups is not valid. This section presents patent activity trends for some of the larger categories. In addition, a detailed breakdown of the thin film material types is presented.

\section{AGGREGATE ACTIVITY}

Figure 4.1 plots the number of patents filed per year over a period of four decades. It thus establishes a baseline for assessing changes in the level of effort in recent years. The figure reveals a dramatic increase in the level of inventive effort following the 1973011 Embargo. The decline in 1981, and to a lesser extent in 1980, is a result of using the filing year to measure activity (see section 3.1). However, the patent activity trends indicate at least a leveling off of the rise in activity experienced in the mid 1970's and suggests a modest downturn below the 80-90 patents per year pace of 1977-80 may be found for 1981 when all the patents filed in 1980 but which issued after 1982 are included for analysis.

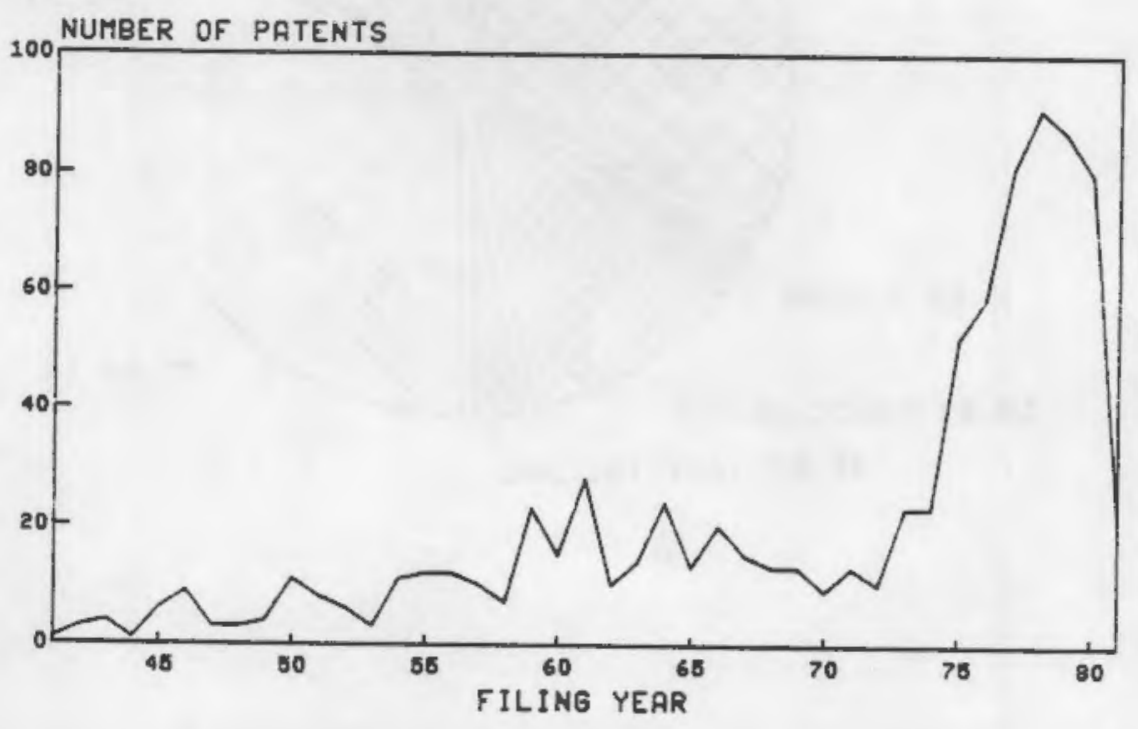

FIGURE 4.1. Photovoltaic Aggregate Patent Activity 


\section{CELL TYPES}

Figure 4.2 reveals the percentage breakdown among cell types for patents which issued between mid-1962 and the end of 1982 . The generic group refers to patents which could be applied to more than one approach, frequently dealing with a process step like doping or annealing. Thin film and $\underline{\mathrm{Cz}}$ type cells were the most numerous type of patents. The number of concentrator patents underestimates somewhat the total inventive effort devoted to this approach since patents related to mechanical tracking means, reflectors mounted on arrays, array cooling means, etc. are not included (see section 2.4). However, patents where the concentrator or cooling means is incorporated in the cell are included.

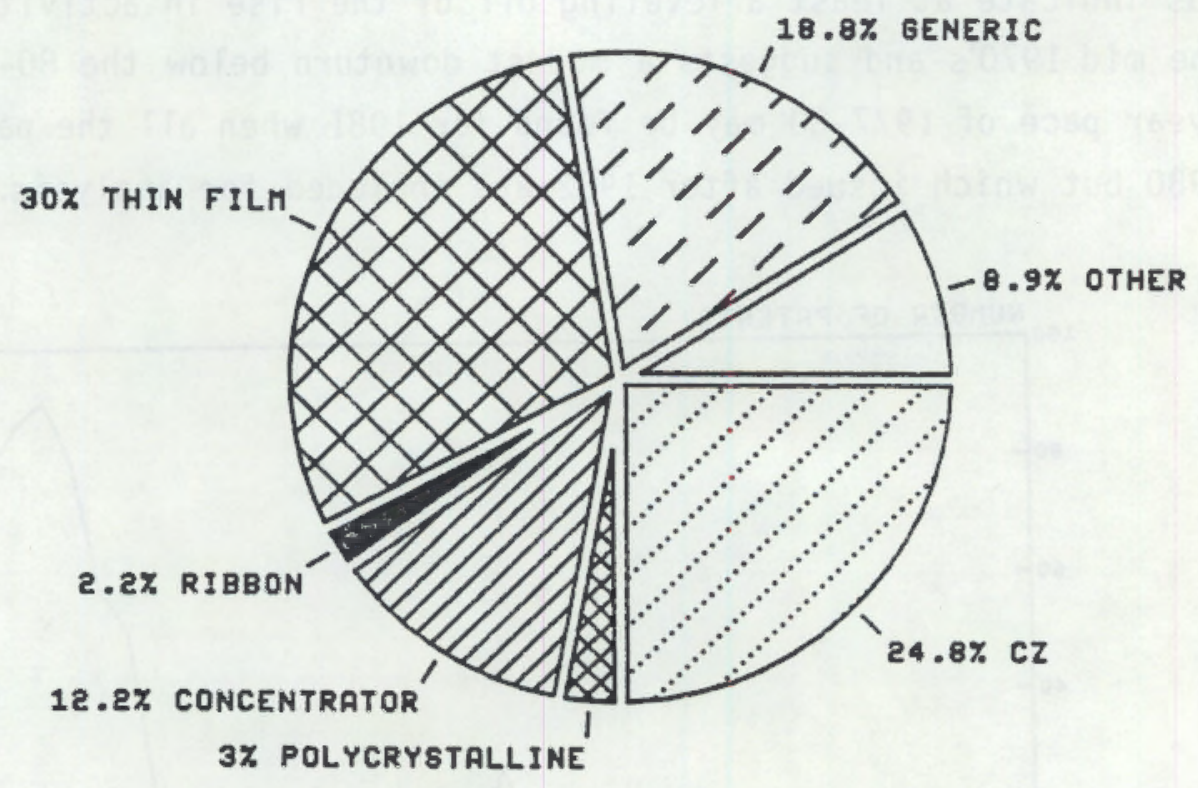

FIGURE 4.2. Photovoltaic Patents - Percentage by Cell Type 
Figures 4.3 and 4.4 plot the trends in patent activity for the major cell types. (Note: the two figures differ in their vertical scale.) Figure 4.3 reveals that the level of patent activity for thin film inventions surpassed those related to $\mathrm{Cz}$ methods in 1978. Because of the delay due to the application process, this fact could have been observed by about 1980. Concentrator cells also became a proportional larger focus of effort starting in 1978.

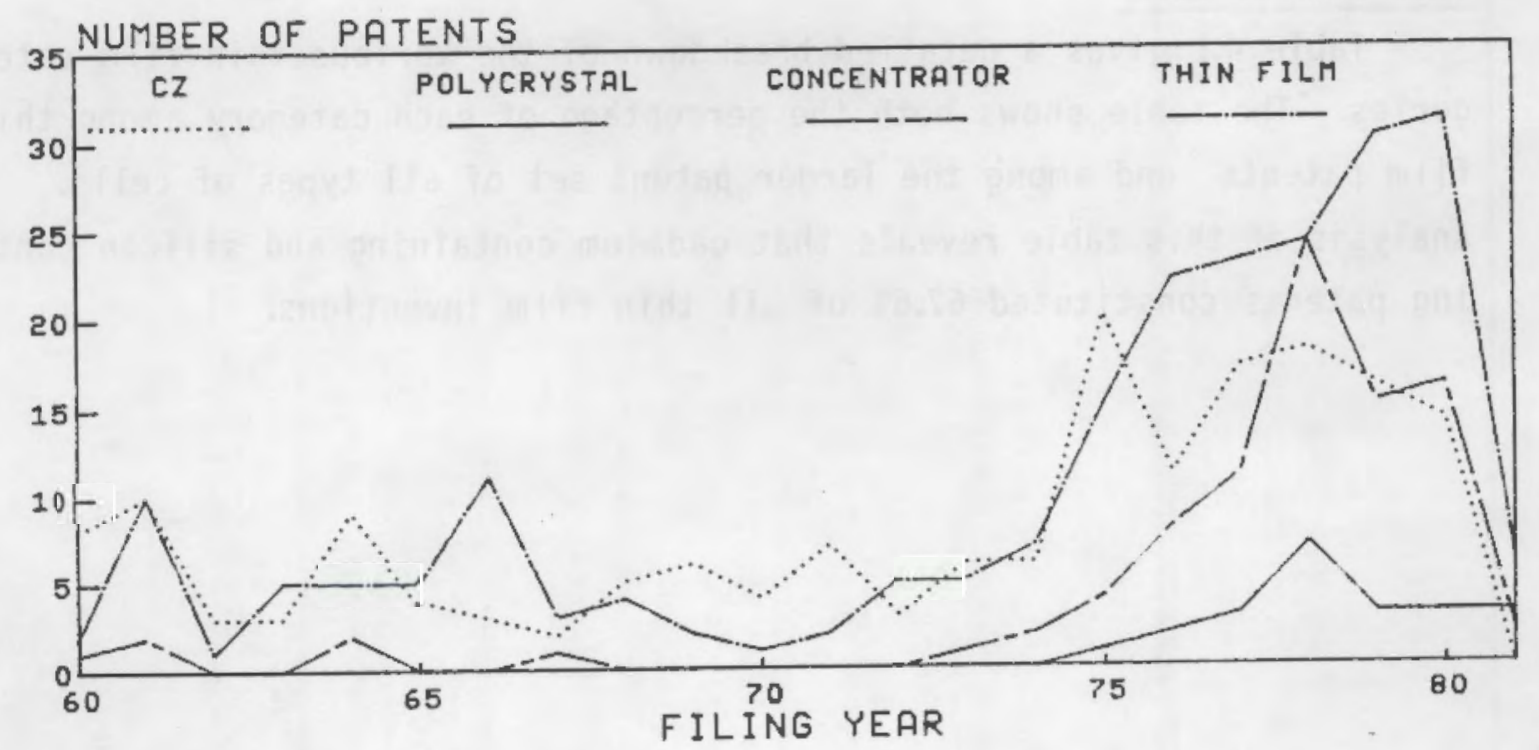

FIGURE 4.3. Patent Activity by Cell Type -- CZ, Polycrystalline, Concentrator, and Thin Film 


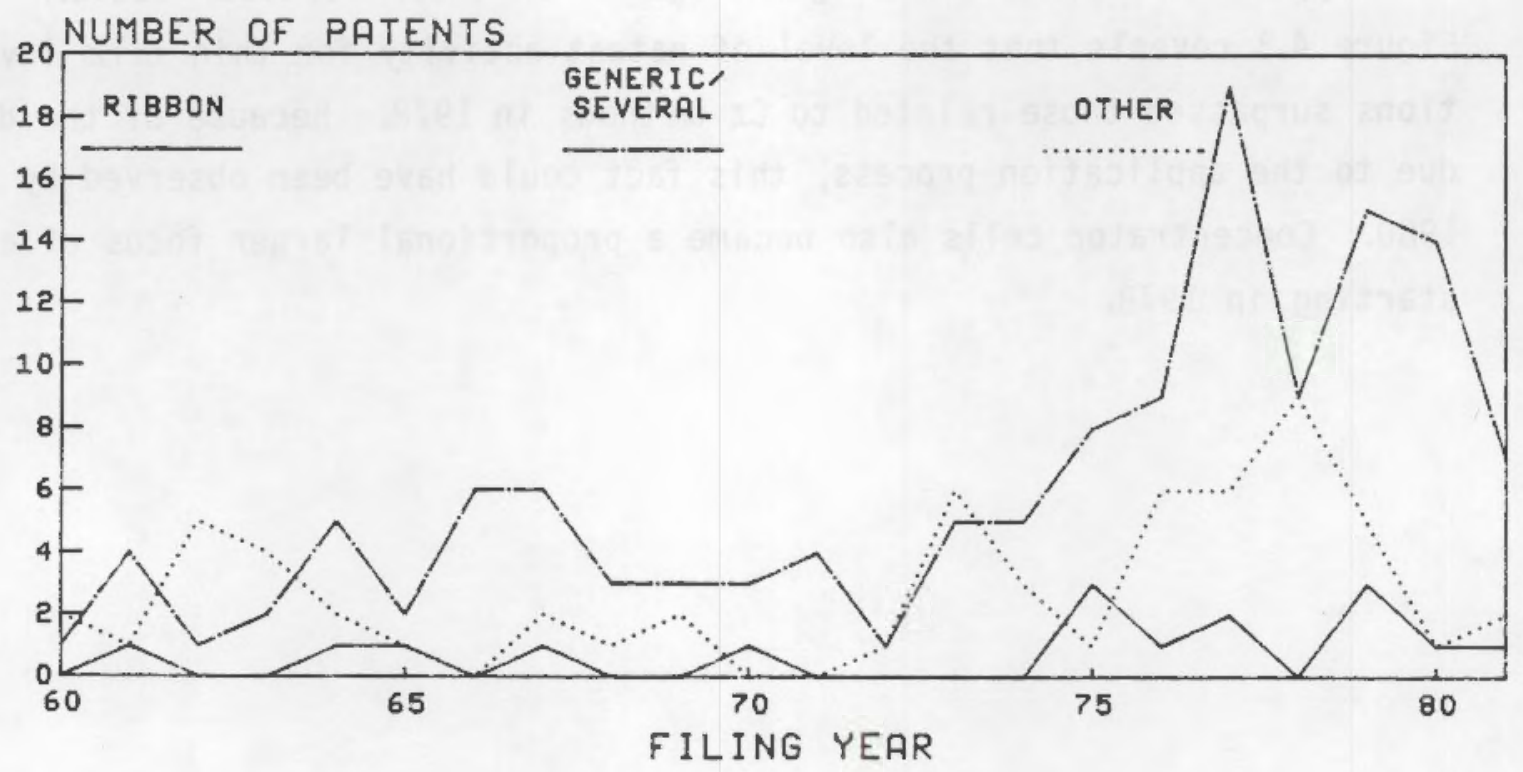

FIGURE 4.4. Patent Activity by Cell Type -- Ribbon, Generic/Several, Other

\section{THIN FILM PATENTS}

Table 4.1 gives a detailed breakdown of the various thin film categories. The table shows both the percentage of each category among thin film patents and among the larger patent set of all types of cells. Analysis of this table reveals that cadmium containing and silicon containing patents constituted $67.6 \%$ of all thin film inventions. 
TABLE 4.1. Thin Film Patent Breakdown

Type

Cadmium Sulfide (or $\mathrm{CdS} / \mathrm{Cu}_{2} \mathrm{~S}$ )

Cadmium Telluride

Cadmium Selenide

Cadmium Multiple (S,Se,Te,etc.)

Subtotal (Cadmium Containing)

Silicon (A-Si, Mono-or Polycrstalline)

Generic/Several Types

Other (e.g.,PbO,FeS, PbTe,Pbs)

Gallium Arsenide

Indium or Zinc Phosphide

Se len ium

Copper Indium di-Selenide

Germanium

TOTAL

\begin{abstract}
Number of
Patents
\end{abstract}

48

8

4

25

85

63

39

11

9

6

3

2

1

219

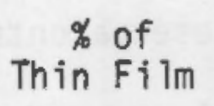

21.9

3.7

1.8

11.4

38.8

28.8

17.8

5.0

4.1

2.7

1.4

.9

.4

30.0
.1

$\%$ of

all PV

6.6

1.1

.5

3.4

11.7

8.6

5.3

1.5

1.2

.8

.4

.3 
Figures 4.5 and 4.6 display the trends in patent activity for these major groups. They reveal that cadmium containing thin film inventions constituted the large majority of thin film patents between 1960 and 1972 . Many of these patents were sensor applications rather than power generation.

It is interesting to note the one silicon thin film patent filed in 1965. The next patent in this category was filed in 1973, a hiatus of eight years.

Figure 4.6 shows that silicon and cadmium containing thin film patent activity was approximately equal between 1973 and 1980 . There are too few patents in 1981 to interpret the significance of the absence of cadmium containing patents for this patent set.

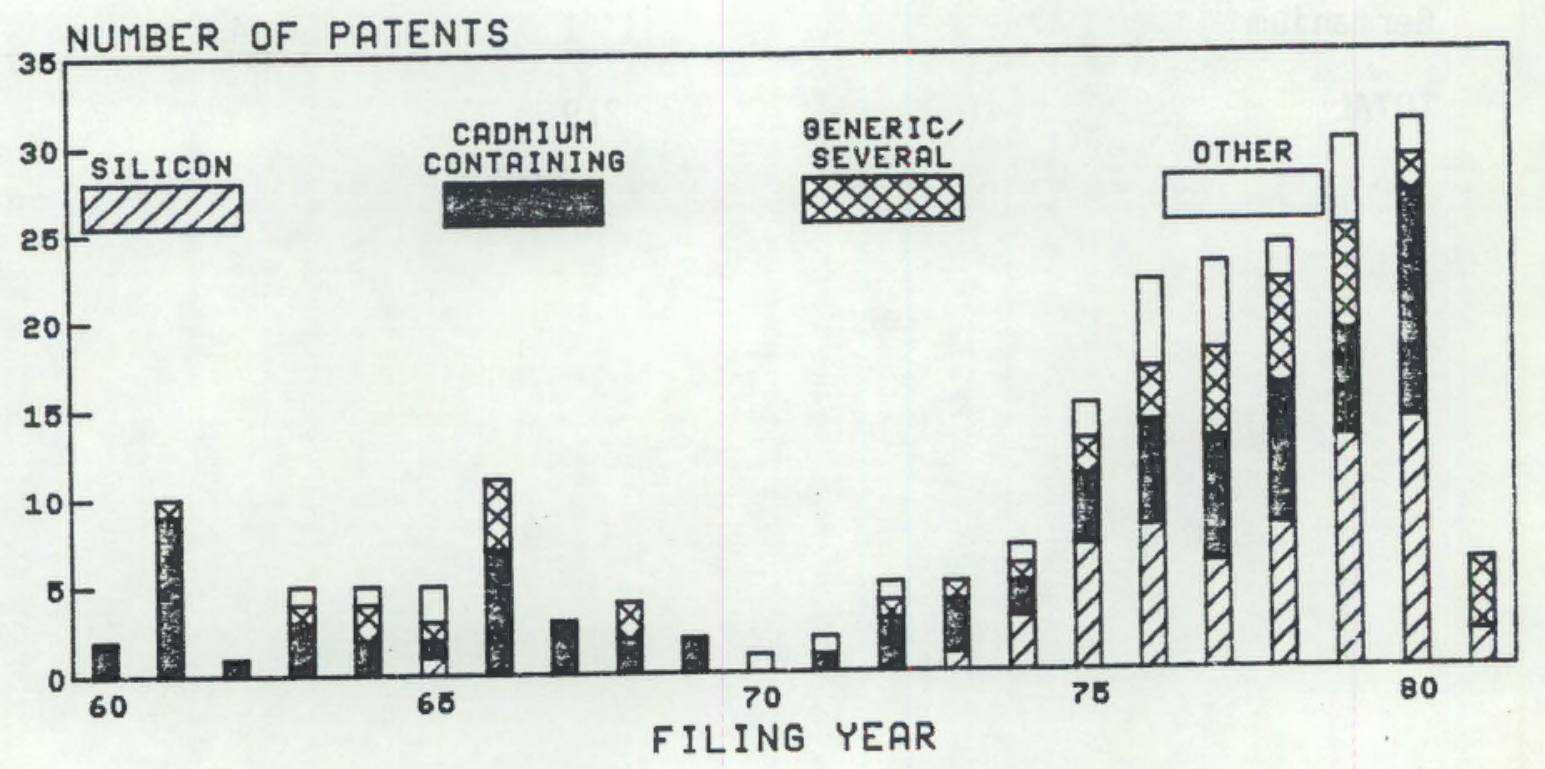

FIGURE 4.5. Thin Film Patent Activity 


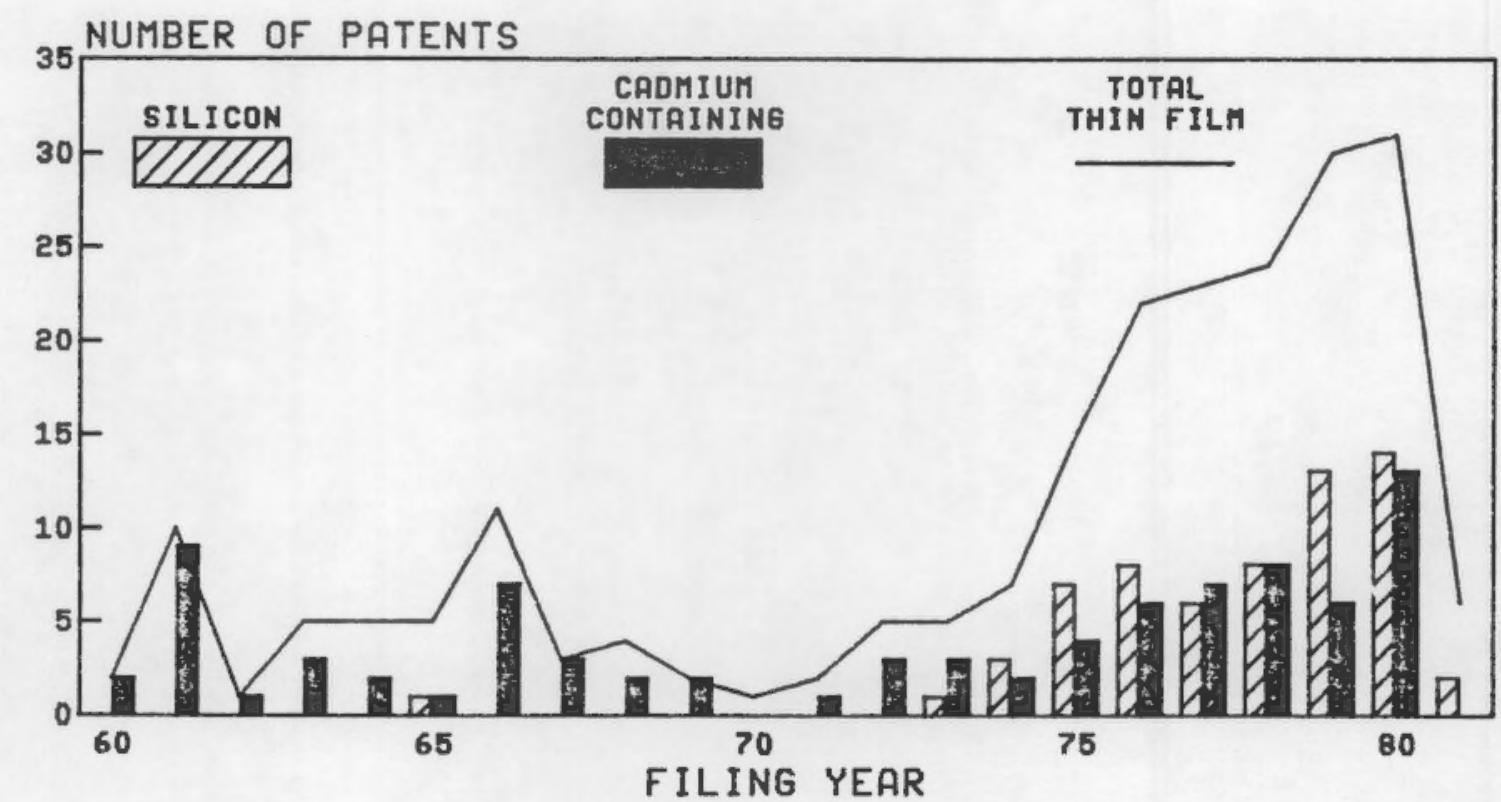

FIGURE 4.6. Thin Film Patent Activity - Silicon/Cadmium Comparison 

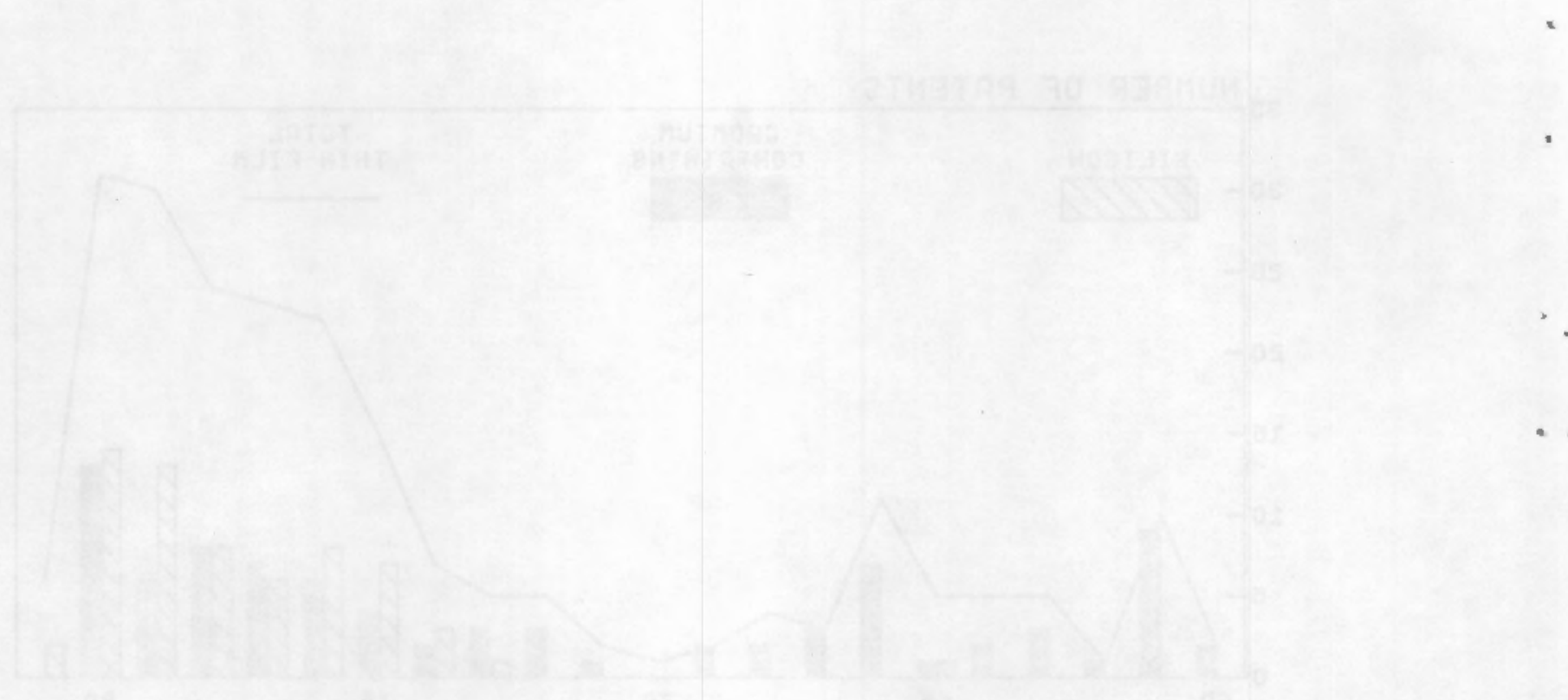

- 


\subsection{CONCLUSIONS}

The primary purpose of this research was to provide information on the nature of patent activity for several types of photovoltaic technology. Such information can aid in the assessment of the status and direction of technological change in this field by identifiying the changing emphasis anong various technical approaches. The major findings of this analysis are as follows:

o The level of inventive activity increased dramatically in the mid1970's. It appears to have peaked in 1978 and remained steady through 1980.

- Thin film and $\mathrm{Cz}$ type photovoltaic cells represent approximately onehalf of the patents analyzed.

o The data indicates that, beginning in 1978, an increasing proportion of inventions in photovoltaic technology were among approaches other than conventional $\mathrm{Cz}$ type cells, particularly thin film and concentrators.

o Among thin film patents, silicon and cadmium containing cells represent about two-thirds of the patent analyzed.

The patents analyzed in this study were issued before 1983. Further insight into technical developments in this field could be obtained by including more recent patents. This could be particularly helpful in assessing recent emphasis among different technical approaches.

patent activity is only one measure of technological change developed by PNL. Other patent indicators which describe the nature of technical developments and the characteristics of firms and inventors could also be used to gain additional insight into the evolution of photovoltaic technology. Patent trend analysis is still a relatively new technique. However, work to date indicates it can be of value in R\&D planning, particularly when combined with other sources of technical and market information. 
REFERENCES

Campbel1, R. S. 1983a. "Patent Trends as a Technological Forecasting Tool". World Patent Information. 5(3):137-143.

Campbe11, R. S. 1983b. "Patenting the Future: A New Way to Forecast Changing Technology." The Futurist, December 1983, pp. 62-67.

Campbel1, R. S., and A. L. Nieves. 1979. "Technology Indicators Based on Patent Data: The Case of the Catalytic Converters-Phase I Report-Design and Demonstration." Prepared for the National Science Foundation under NSF Grant PRA 78-20321, PB 82146150, National Technical Information Service, Springfield, Virginia.

Garrett-Price, B. A. et al. 1984. Industrial Fouling: Problem Characterization, Economic Assessment, and Review of Prevention, Mitigation, and Accommodation Techniques. PNL-4883. Pacific Northwest Laboratories, Richland, Washington.

Levine, L. O., W. B. Ashton, and R. S. Campbell. 1984. A Preliminary Analysis of Patent Trends for Magnetic Fusion Technology. PNL-4932. Pacific Northwest Laboratories, Richland, Washington.

U.S. Patent Office. 1979. Manual of Classification. Revison No. 6 April 1981. U.S. Government Printina Office, Washington, D.C.

Wiseman, P. 1983. "Patenting and Inventive Activity on Synthetic Fibre Intermediates." Research Policy. 12(1983):329-339. 
.

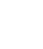




\section{DISTRIBUTION}

No, of

Copies

OFFSITE

27 DOE Technical Information

Andrew Krantz

Department of Energy

Forrestal Building

Washington, DC 20056

Vince Rice

Department of Energy

Forrestal Building

Washington, DC 20056

Robert Ferber

Jet Propulsion Laboratory

4800 Dak Grove Drive

Pascadena, CA 91103

Don Ritchie

Solar Energy Research Inst.

1617 Cole Blvd.

Golden, CO 80401
No. of

Copies

ONSITE

DOE Richland Operations Office

H. E. Ransom/D. R. Segna

$30 \quad$ Pacific Northwest Laboratory

W. B. Ashton

C. H. Bloomster

R. S. Campbell

R. M. Fleischman

L. 0. Levine (15)

A. L. Slavich

S. A. Smith

M. B. Triplett

R. L. Watts

Publishing Coordination (2)

Technical Information (5) 


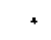

